\title{
Internationalisering van het medisch onderwijs: de stand van zaken
}

\author{
G.D. Majoor, S. Niemantsverdriet, M.M. Groen, G.E.A. ten Have, C.E. Hulstaert, \\ M.A.J. Nijenhuis, M.A.T.M. Vorstenbosch, S.C. Willemstein
}

\section{Samenvatting}

Inleiding: Internationalisering heeft de afgelopen vijftien jaar in het medisch onderwijs veel aandacht gekregen. In dit artikel wordt een onderzoek gerapporteerd naar de stand van zaken aan zeven medische faculteiten in het academisch jaar 2000/2001 betreffende aantallen uitgaande en inkomende studenten, kwaliteitszorg voor buitenlandse stages, aandacht voor internationalisering in het curriculum, en de invloed van stimuleringsmaatregelen op de ontwikkeling van internationalisering.

Methode: Gegevens zijn verzameld door middel van een enquête onder de coördinatoren internationalisering van zeven medische faculteiten.

Resultaten: Per faculteit volgen gemiddeld 107 studenten onderwijs in het buitenland (range 53-243) en worden er 38 buitenlandse studenten (range 12-77) ontvangen. Tussen 1998 en 2002 steeg het gemiddelde aantal inkomende studenten geleidelijk van 27 tot 38 per jaar. Stages in geïndustrialiseerde landen betreffen vooral onderzoek; in ontwikkelingslanden is klinisch onderwijs het meest in trek. Inkomende studenten nemen deel aan regulier en klinisch onderwijs en aan onderzoek. Alle faculteiten hebben procedures om de kwaliteit van de buitenlandse stages te bewaken. In alle curricula wordt aandacht besteed aan internationalisering, zij het vaak door middel van facultatief onderwijs. Van de stimuleringsmaatregelen worden die van de eigen universiteit of faculteit als het meest effectief beschouwd.

Conclusies: Er zijn grote verschillen tussen de faculteiten in studentenmobiliteit. Het zou aanbeveling verdienen om maatregelen om de kwaliteit van de stages te bewaken onderling af te stemmen. Internationalisering kan bevorderd worden door opname in het reguliere curriculum. De geënquêteerden zijn van mening dat internationalisering het meest gestimuleerd wordt door maatregelen van de eigen faculteit of universiteit. (Majoor GD, Niemantsverdriet S, Groen MM, Have GEA ten, Hulstaert CE, Nijenhuis MAJ, Vorstenbosch MATM, Willemstein SC. Internationalisering van het medisch onderwijs: de stand van zaken. Tijdschrift voor Medisch Onderwijs 2003;22(1):18-27.)

\section{Inleiding}

Onder internationalisering van het medisch onderwijs wordt het streven verstaan om in de studie geneeskunde elementen in te bouwen die het de afgestudeerde arts mogelijk moeten maken om ook in een internationale context goed te kunnen functioneren. De rationale voor internationalisering van het medisch curriculum is dat vrijwel alle artsen in hun professioneel functioneren geconfronteerd zullen wor- den met allochtone patiënten en patiënten met allerlei importziekten. In onderzoek en nascholing is een internationale oriëntatie tegenwoordig eerder regel dan uitzondering en ook daarop moeten aankomende artsen, bijvoorbeeld door training in het gebruik van (medisch) Engels, in de studie adequaat worden voorbereid. ${ }^{1}$

In het Raamplan 2001 artsopleiding worden onder kennis en inzicht met betrekking tot de gezondheidszorg "verschil- 
len van de Nederlandse gezondheidszorg in relatie tot de andere gezondheidszorgsystemen in Europa en de rest van de wereld" genoemd, en onder medische ethiek kennis met betrekking tot algemene vragen betreffende "ethiek en interculturalisatie". ${ }^{2}$ Interculturalisatie is door de Raad voor de Volksgezondheid en Zorg als volgt gedefinieerd: "Interculturalisatie van de gezondheidszorg betreft een beleid gericht op het cultuurgevoeliger maken van voorzieningen in de gezondheidszorg met het doel allochtone en autochtone (potentiële) zorgvragers gelijkwaardige kwaliteit van en gelijke toegang tot de zorg te verschaffen". 3

Majoor en Willemstein identificeerden in 1996 twee hoofdcomponenten van internationalisering: internationale uitwisseling van studenten (uitgaande en inkomende studentenmobiliteit) en internationalisatie in het medisch curriculum. ${ }^{1}$ Onder andere op grond van dat artikel worden in deze studie zes aspecten van internationalisering in het curriculum onderscheiden:

- aanbod van regulier onderwijs in de Engelse taal;

- faciliteiten voor training in andere talen; - aandacht voor tropische (import-)ziekten;

- training in het omgaan met allochtone patiënten;

- gezondheidszorgsystemen in het buitenland;

- interculturalisatie van het medisch curriculum.

Met betrekking tot het laatste onderwerp is onlangs een rapport uitgebracht waarin de stand van zaken aan alle medische faculteiten wordt beschreven. ${ }^{4}$ Dit aspect is daarom niet betrokken in het in dit artikel beschreven onderzoek.

Internationalisering van het hoger onderwijs heeft de afgelopen vijftien jaar veel aandacht gekregen. In Europa heeft het Erasmus-programma van de Euro- pese Commissie (EC) sinds 1987 een stimulans gegeven aan met name de mobiliteit van studenten tussen de lidstaten van de Europese Unie. ${ }^{5}$ Later zijn daar nog nationale stimuleringsprogramma's (zoals STIR van het Ministerie van Onderwijs) en intercontinentale stimuleringsprogramma's (zoals Alpha van de EC) bijgekomen. Er zijn diverse redenen waarom de mobiliteit van geneeskundestudenten aanvankelijk achterbleef bij die van studenten in andere vakgebieden. Een rol hierin speelden bijvoorbeeld de grote variatie in de structuur van medische curricula, verschillende planning van verplichte examens, ontbreken van een internationaal studiepuntensysteem in Europa, en de voordelen van 'thuisblijven' in de competitie om opleidingsplaatsen na de basisartsopleiding. ${ }^{6}$ Om ook in Nederland een impuls te geven aan internationalisering in de faculteiten geneeskunde is in 1987 door het Disciplineoverlegorgaan Medische Wetenschappen (DMW) van de Vereniging van Samenwerkende Nederlandse Universiteiten (VSNU) een Werkgroep Internationalisering (DMW-INT) ingesteld, waarin de coördinatoren internationalisering van de acht medische faculteiten zitting hebben. In die tijd waren er grote verschillen in de aandacht voor internationalisering tussen de faculteiten. ${ }^{7}$ Dit was aanleiding om op het Gezond Onderwijs Congres van de Nedeerlandse Vereniging voor Medisch Onderwijs en in het Nederlands Tijdschrift voor Geneeskunde aandacht voor dit onderwerp te vragen. 891 Inmiddels is internationalisering een erkend aspect van de medische opleiding. In de visitatie van 1997 en de komende visitatie van 2003 wordt het nadrukkelijk meegewogen in de beoordeling van het onderwijsprogramma. ${ }^{10}$

De coördinatoren internationalisering van de medische faculteiten ontmoeten 
elkaar één tot twee keer per jaar in de DMW-INT om informatie uit te wisselen over beleid en problemen op het gebied van internationalisering van het medisch onderwijs. Op een bijeenkomst van DMWINT in maart 2002 is besloten om gezamenlijk te rapporteren over de stand van zaken met betrekking tot internationalisering aan de medische faculteiten. Deze rapportage heeft betrekking op de volgende onderzoeksvragen:

1. Wat is de kwantiteit van de uitgaande en inkomende studentenmobiliteit aan de medische faculteiten?

2. Hoe wordt de kwaliteit van stages in het buitenland verzekerd?

3. Aan welke aspecten van internationalisering wordt in het medisch curriculum aandacht besteed en op welke wijze?

4. Welke invloed hebben internationale, nationale of lokale stimuleringsmaatregelen gehad op de ontwikkeling van internationalisering aan de verschillende faculteiten?

\section{Methode}

Aan de coördinatoren internationalisering van de medische faculteiten is een elektronische enquête toegezonden bestaand uit gesloten en open vragen over de stand van zaken met betrekking tot internationalisering. De gesloten vragen hadden betrekking op de kwantiteit van de studentenmobiliteit, de bestemming van uitgaande studenten en de herkomst van inkomende studenten, en de aard van het door inkomende en uitgaande studenten gevolgde onderwijs (regulier en klinisch onderwijs of onderzoek). De herkomst van inkomende en de bestemming van uitgaande studenten is opgesplitst in ontwikkelingslanden of geïndustrialiseerde landen. De coördinatoren konden hun mening omtrent de invloed van stimuleringsmaatregelen op de internatio- nalisering in hun faculteit aangeven op een vierpunts Likertschaal (1=grote invloed; 2 =enige invloed; $3=$ weinig invloed; 4=zeer geringe invloed). Verder werden er open vragen gesteld over de kwaliteitsbewaking van studieprogramma's in het buitenland en de aandacht in het curriculum voor de vijf eerder genoemde aspecten van internationalisering. Een laatste open vraag bood de mogelijkheid om toelichting te geven en opmerkingen te plaatsen.

Als peiljaar werd het academisch jaar 2000/2001 genomen. Alleen met betrekking tot de absolute aantallen uitgaande en inkomende studenten zijn ook de getallen van de twee voorgaande jaren opgenomen om te beoordelen of de gegevens voor het peiljaar als uitbijter moesten worden beschouwd.

\section{Resultaten}

\section{Respons op de enquête}

Zeven van de acht coördinatoren internationalisering hebben de enquête ingevuld geretourneerd. De coördinator internationalisering van het Medisch Centrum van de Vrije Universiteit zag van deelname af. Er deden dus zeven faculteiten mee: het Academisch Medisch Centrum van de Universiteit van Amsterdam (AMC-A), het Erasmus Medisch Centrum Rotterdam (EMC), het Leids Universitair Medisch Centrum (LUMC), de Universiteit Maastricht (UM), het Universitair Medisch Centrum Sint Radboud in Nijmegen (UMCSR), het Universitair Medisch Centrum Utrecht (UMCU) en de Rijksuniversiteit Groningen (RUG).

\section{Kwantiteit van studentenmobiliteit}

Het gemiddeld aantal uitgaande studenten per faculteit was in het peiljaar 107 (range 53-243), terwijl het gemiddelde aantal inkomende studenten 38 bedroeg 
(range 12-77) (tabel 1). Het gemiddelde aantal uitgaande studenten was stabiel over de drie onderzochte jaren: 99 in 1998/1999, 104 in 1999/2000 en 107 in 2000/2001. Het jaarlijkse aantal inkomende studenten vertoont een geleidelijke stijging: 27 in 1998/1999, 32 in 1999/2000 en 38 in 2000/2001. Bij vier faculteiten trad er in 2000/2001 een aanzienlijke stijging op in het aantal inkomende studenten ten opzichte van 1999/2000. In het AMC-A steeg het aantal van 11 naar 18 (82\%), in het EMC van 28 naar $52(86 \%)$, in het LUMC van 34 naar 50 (47\%) en in het UMCSR van 7 naar 12 (71\%).

\section{Bestemming van uitgaande studenten en} aard van het gevolgde onderwijs

Als de uitgaande studenten voor alle zeven faculteiten tezamen worden genomen, blijken de aantallen studenten die naar bestemmingen in geïndustrialiseerde landen (376 studenten) en ontwikkelingslanden (306 studenten) gaan vergelijkbaar te zijn (tabel 2).

Per faculteit kan het beeld echter aanmerkelijk van het landelijk gemiddelde ver- schillen: de RUG zag in het peiljaar procentueel de meeste studenten naar geïndustrialiseerde landen reizen $(86 / 106 ; 81 \%)$ en vanuit de UM gingen de meeste studenten naar ontwikkelingslanden (139/239; 57\%).

Van de studenten die naar geïndustrialiseerde landen gaan, neemt 59\% deel aan onderzoek. Van de studenten die naar die landen gaan, volgt 32\% klinisch onderwijs en neemt slechts $9 \%$ deel aan regulier onderwijs. Van de studenten die naar ontwikkelingslanden gaan, neemt $70 \%$ deel aan klinisch onderwijs en $29 \%$ aan onderzoek. In die landen wordt maar zelden aan regulier onderwijs deelgenomen (1\%).

\section{Herkomst van inkomende studenten en aard van het gevolgde onderwijs}

Er is een groot verschil tussen het aantal inkomende studenten uit geïndustrialiseerde landen (219) en ontwikkelingslanden (47) (tabel 3). Ongeacht de herkomst van de inkomende studenten is hun deelname aan de verschillende typen onderwijs aan alle faculteiten tezamen gelijkmatig verdeeld. 30\% (79/266) neemt deel aan klinisch onderwijs, 38\% (101/266) aan re-

Tabel 1. Kwantiteit van de studentenmobiliteit 1998/1999 - 2000/2001.

\section{Aantal studenten}

\begin{tabular}{|c|c|c|c|c|c|c|c|}
\hline \multirow[b]{2}{*}{ Faculteit } & \multirow{2}{*}{$\begin{array}{l}\text { Totaal aantal } \\
\text { ingeschreven } \\
2000 / 2001^{1}\end{array}$} & \multicolumn{3}{|c|}{ Uitgaand } & \multicolumn{3}{|c|}{ Inkomend } \\
\hline & & $98 / 99$ & $99 / 00$ & $00 / 01$ & $98 / 99$ & $99 / 00$ & $00 / 01$ \\
\hline AMC-A & 1670 & 111 & 119 & 112 & 7 & 11 & 18 \\
\hline EMC & 1679 & 52 & 58 & 61 & 28 & 28 & 52 \\
\hline LUMC & 1303 & 32 & 50 & 53 & 20 & 34 & 50 \\
\hline UM & 1325 & 209 & 218 & 243 & 63 & 89 & 77 \\
\hline UMCSR & 1362 & 75 & 74 & 66 & 8 & 7 & 12 \\
\hline $\mathrm{UMCU}^{2}$ & 1588 & 104 & 107 & 95 & 11 & 13 & 15 \\
\hline RUG & 1612 & 113 & 101 & 106 & 49 & 41 & 42 \\
\hline Gemiddeld & 1506 & 99 & 104 & 107 & 27 & 32 & 38 \\
\hline
\end{tabular}

1 Ingeschreven studenten per 01-12-2000. Bron: Centraal Bureau voor de Statistiek.

2 Aantallen studenten van het UMCU zijn exclusief de aantallen studenten uitgewisseld door IFMSAUtrecht (IFMSA: International Federation of Medical Students Associations). 
gulier (keuze-)onderwijs en 32\% (86/266) aan onderzoek. Per faculteit kunnen de percentages aanmerkelijk van het landelijk gemiddelde afwijken. Aan de RUG neemt 59\% (25/42) van de inkomende stu- denten deel aan klinisch onderwijs, aan de UM neemt 65\% (50/77) deel aan regulier onderwijs en in het AMC-A en het LUMC neemt respectievelijk 67\% (12/18) en 66\% (33/50) deel aan onderzoek.

Tabel 2. Bestemming en aard van onderwijs van uitgaande studenten 2000/2001 (in aantallen studenten).

\begin{tabular}{|c|c|c|c|c|c|c|c|}
\hline \multirow[b]{4}{*}{ Faculteit } & \multicolumn{7}{|c|}{ Bestemming } \\
\hline & \multirow{2}{*}{\multicolumn{3}{|c|}{$\begin{array}{c}\text { Geïndustrialiseerde landen } \\
\text { Type onderwijs }\end{array}$}} & \multirow{2}{*}{\multicolumn{3}{|c|}{$\begin{array}{c}\text { Ontwikkelingslanden } \\
\text { Type onderwijs }\end{array}$}} & \multirow[b]{3}{*}{ Totaa } \\
\hline & & & & & & & \\
\hline & Klinisch & $\begin{array}{l}\text { Regulier } \\
\text { keuzeow. }\end{array}$ & $\begin{array}{l}\text { Onder- } \\
\text { zoek }\end{array}$ & Klinisch & $\begin{array}{l}\text { Regulier } \\
\text { keuzeow. }\end{array}$ & $\begin{array}{l}\text { Onder- } \\
\text { zoek }\end{array}$ & \\
\hline$A M C-A^{1}$ & 1 & 0 & 30 & 17 & 0 & 14 & 62 \\
\hline EMC & 10 & 19 & 15 & 6 & 4 & 7 & 61 \\
\hline LUMC & 5 & 13 & 15 & 5 & 0 & 15 & 53 \\
\hline UM & 64 & 2 & 38 & 112 & 0 & 23 & 239 \\
\hline UMCSR & 7 & 1 & 20 & 28 & 0 & 10 & 66 \\
\hline UMCU & 20 & 0 & 30 & 36 & 0 & 9 & 95 \\
\hline RUG & 13 & 0 & 73 & 11 & 0 & 9 & 106 \\
\hline Totaal (absoluut) & 120 & 35 & 221 & 215 & 4 & 87 & 682 \\
\hline Totaal (relatief) & $32 \%$ & $9 \%$ & $59 \%$ & $70 \%$ & $1 \%$ & $29 \%$ & \\
\hline
\end{tabular}

1 Exclusief 50 studenten (35 verpleegstage, 15 wetenschapsstage) van wie de bestemming niet is geregistreerd.

Tabel 3. Herkomst en aard van onderwijs van inkomende studenten 2000/2001.

\begin{tabular}{|c|c|c|c|c|c|c|c|}
\hline \multirow[b]{4}{*}{ Faculteit } & \multicolumn{7}{|c|}{ Herkomst } \\
\hline & \multirow{2}{*}{\multicolumn{3}{|c|}{$\begin{array}{c}\text { Geïndustrialiseerde landen } \\
\text { Type onderwijs }\end{array}$}} & \multicolumn{4}{|c|}{ Ontwikkelingslanden } \\
\hline & & & & \multicolumn{3}{|c|}{ Type onderwijs } & \multirow[b]{2}{*}{ Totaal } \\
\hline & Klinisch & $\begin{array}{l}\text { Regulier } \\
\text { keuzeow. }\end{array}$ & $\begin{array}{l}\text { Onder- } \\
\text { zoek }\end{array}$ & Klinisch & $\begin{array}{l}\text { Regulier } \\
\text { keuzeow. }\end{array}$ & $\begin{array}{l}\text { Onder- } \\
\text { zoek }\end{array}$ & \\
\hline AMC-A & 6 & 0 & 11 & 0 & 1 & 1 & 18 \\
\hline EMC & 8 & 25 & 4 & 5 & 6 & 4 & 52 \\
\hline LUMC & 7 & 10 & 30 & 0 & 0 & 3 & 50 \\
\hline UM & 14 & 41 & 3 & 3 & 9 & 7 & 77 \\
\hline UMCSR & 5 & 0 & 2 & 0 & 5 & 0 & 12 \\
\hline $\mathrm{UMCU}^{2}$ & 6 & 1 & 7 & 0 & 0 & 1 & 15 \\
\hline RUG & 23 & 4 & 12 & 2 & 0 & 1 & 42 \\
\hline Totaal (absoluut) & 69 & 81 & 69 & 10 & 20 & 17 & 266 \\
\hline Totaal (relatief) & $31 \%$ & $37 \%$ & $31 \%$ & $21 \%$ & $43 \%$ & $36 \%$ & \\
\hline
\end{tabular}




\section{Kwaliteitscontrole op onderwijs in het buitenland}

Alle zeven faculteiten bewaken de kwaliteit van het onderwijs in het buitenland, zij het op verschillende manieren. Soms wordt de beoordeling van de prestaties van studenten in het buitenland aan de externe begeleider overgelaten, maar vaker wordt het oordeel van de externe docent meegewogen in de uiteindelijke beoordeling door een of meer docenten van de thuisfaculteit. In iedere faculteit dient de student voor vertrek naar het buitenland voor keuzeonderwijs, wetenschapsstage of (keuze-)co-assistentschap toestemming van een docent of een commissie van docenten te verkrijgen. Bij de beoordeling van een verzoek worden meestal dezelfde kwaliteitseisen gehanteerd als voor vergelijkbaar onderwijs in de eigen faculteit of elders in Nederland. Er dient altijd een externe begeleider (in het buitenland) geïdentificeerd te zijn.

\section{Internationalisering van het curriculum}

De stand van zaken met betrekking tot de vijf onderzochte aspecten van internationalisering in het curriculum is beknopt weergegeven in tabel 4. Alleen UM en LUMC bieden een deel van het reguliere curriculum in het Engels aan. In vijf van de zeven faculteiten zijn er faciliteiten voor training in het Engels of in andere talen.

Vier van de zeven faculteiten bieden facultatief, bijvoorbeeld in het kader van het keuzeonderwijs, onderwijs in tropische (import-)ziekten aan. Twee faculteiten hebben dit onderwerp in het curriculum geïntegreerd en in één faculteit is het onderwerp niet vertegenwoordigd.

Tabel 4. Internationalisering van het curriculum.

\begin{tabular}{|c|c|c|c|c|c|c|c|}
\hline $\begin{array}{l}\text { Aspect van } \\
\text { internatio- } \\
\text { nalisering }\end{array}$ & AMC-A & EMC & LUMC & UM & UMCSR & UMCU & RUG \\
\hline $\begin{array}{l}\text { Engelstalig } \\
\text { onderwijs }\end{array}$ & - & - & $\begin{array}{c}\text { 1e semester } \\
\text { jaar } 2\end{array}$ & $\begin{array}{l}18 \text { wk. } \\
\text { jaar } 4\end{array}$ & $\begin{array}{c}\text { Keuze- } \\
\text { onderwijs }\end{array}$ & - & - \\
\hline Taal & Swahili & - & Engels & $\begin{array}{c}\text { Engels } \\
\text { facultatief }\end{array}$ & $\begin{array}{c}\text { Spaans } \\
\text { Swahili } \\
\text { Sranatongo }\end{array}$ & - & $\begin{array}{c}\text { Verplicht } \\
\text { voor } \\
\text { uitgaande } \\
\text { studenten }\end{array}$ \\
\hline $\begin{array}{l}\text { Import- } \\
\text { ziekten }\end{array}$ & Facultatief & Facultatief & $\begin{array}{c}\text { Geïntegreerd } \\
+ \text { keuze } \\
\text { onderwijs }\end{array}$ & Geïntegreerd & $\begin{array}{c}\text { Keuze- } \\
\text { onderwijs }\end{array}$ & - & $\begin{array}{c}\text { Keuze- } \\
\text { onderwijs }\end{array}$ \\
\hline $\begin{array}{l}\text { Omgaan met } \\
\text { allochtone } \\
\text { patiënten }\end{array}$ & $\begin{array}{l}\text { Geïnte- } \\
\text { greerd }\end{array}$ & $\begin{array}{c}\text { Inherent aan } \\
\text { patiënten } \\
\text { populatie }\end{array}$ & $\begin{array}{c}\text { Keuze- } \\
\text { onderwijs }\end{array}$ & - & $\begin{array}{c}\text { Keuze- } \\
\text { onderwijs }\end{array}$ & $\begin{array}{c}\text { Keuze- } \\
\text { onderwijs }\end{array}$ & - \\
\hline $\begin{array}{l}\text { Gezond- } \\
\text { heidszorg } \\
\text { buitenland }\end{array}$ & $\begin{array}{l}\text { In co-schap } \\
\text { in ontwikke- } \\
\text { lingsland }\end{array}$ & + & $\begin{array}{c}\text { Keuze- } \\
\text { onderwijs }\end{array}$ & - & $\begin{array}{c}\text { Keuze- } \\
\text { onderwijs }\end{array}$ & - & - \\
\hline $\begin{array}{l}\text { Andere } \\
\text { aspecten }\end{array}$ & $\begin{array}{l}\text { Summer } \\
\text { school }\end{array}$ & $\begin{array}{c}\text { Zoeken op } \\
\text { internet }\end{array}$ & - & - & - & $\begin{array}{c}\text { Summer } \\
\text { school }\end{array}$ & - \\
\hline
\end{tabular}


Door de multiculturele patiëntenpopulatie in de ziekenhuizen in de grote steden worden de studenten in het AMC-A en het EMC in het klinisch onderwijs onvermijdelijk geconfronteerd met allochtone patiënten. Door drie andere faculteiten (LUMC, UMCSR en UMCU) wordt alleen in het keuzeonderwijs aandacht aan de omgang met allochtone patiënten besteed. Drie faculteiten besteden geen expliciete aandacht aan dit onderwerp.

Gezondheidszorgsystemen in het buitenland zijn als onderwerp alleen in het AMC-A en in het EMC in het reguliere curriculum opgenomen. Het LUMC en het UMCSR bieden over dit onderwerp keuzeonderwijs aan. Elders wordt er aan dit onderwerp geen expliciete aandacht besteed.

Naast de benoemde aspecten werd er in de enquête ook naar mogelijke andere relevante aspecten gevraagd. AMCA en UMCU noemden daar hun 'Summerschools', waaraan wordt deelgenomen door buitenlandse studenten (deze zijn niet meegeteld in tabel 1) en het EMC wijst op een cursus waarin studenten geleerd wordt hoe het internet te exploreren.

\section{Invloed van stimuleringsbeleid op internationalisering}

De coördinatoren internationalisering werd gevraagd om aan te geven in welke mate stimuleringsbeleid op mondiaal, Europees, nationaal of universitair/facultair niveau van invloed is geweest op de huidige stand van zaken. De coördinatoren hebben aangegeven op een vierpuntsschaal ( 1 =grote invloed tot en met $4=$ zeer geringe invloed) dat stimuleringsbeleid op universitair/facultair niveau de meeste invloed heeft gehad (gemiddelde score respectievelijk 1.5 en 1.7). Drie respondenten hebben facultair beleid gelijkgesteld aan universitair beleid, zodat daartussen geen onderscheid kan worden gemaakt. Stimuleringsbeleid op nationaal en Europees niveau volgen daarna met een gemiddelde score van respectievelijk 2.3 en 2.4. Van beleid op mondiaal niveau wordt weinig of geen invloed geconstateerd (gemiddelde score 3.2). Ook hier zijn er weer aanzienlijke verschillen tussen de faculteiten. Zo schrijven het AMC-A en het UMCSR grote invloed toe aan nationaal stimuleringsbeleid, terwijl het EMC en de UM daar slechts een zeer geringe invloed van aangeven.

\section{Discussie en conclusies}

Zeven van de acht medische faculteiten hebben de enquête ingevuld. Er is dus geen reden om de representativiteit van de gegevens in twijfel te trekken. Wel moet hierbij worden aangetekend dat andere gegevens dan de kwantitatieve slechts door één deskundige werden verwoord. Uitgebreidere consultatie van betrokkenen binnen een faculteit zou tot andere antwoorden kunnen leiden.

Er zijn geen systematische fouten die in aanmerking moeten worden genomen met betrekking tot de in tabel 1 gepresenteerde absolute aantallen inkomende en uitgaande studenten. Wel bleek het sommige coördinatoren internationalisering moeite te kosten om de globale gegevens zoals gepresenteerd in tabel 1 aan te leveren. De reden daarvoor was bij ten minste één faculteit (UMCU) dat de gegevens van de faculteit en de lokale tak van de International Federation of Medical Students Associations (IFMSA) niet jaarlijks in een gegevensbestand worden geïntegreerd.

De absolute aantallen uitgaande studenten zijn in drie opeenvolgende academische jaren per faculteit stabiel. Er is dus geen sprake van uitbijters in het peiljaar 2000/2001. Ter informatie zijn in tabel 1 ook per faculteit de aantallen ingeschre- 
ven studenten per 1 december 2000 vermeld. De aantallen uitgaande studenten zijn niet gepresenteerd als percentage van het totaal aantal ingeschreven studenten omdat aan sommige faculteiten studenten in bepaalde studiejaren geen mogelijkheid hebben om naar het buitenland te gaan. Het relatief grote aantal uitgaande studenten aan de UM kan niet verklaard worden uit mobiliteit naar Aken en Luik, die verwaarloosbaar klein is.

De gemiddelde aantallen inkomende studenten vertonen over de drie onderzochte jaren een stijgende trend. Aan vier faculteiten is er in 2000/2001 sprake van een forse toename van het aantal inkomende studenten ten opzichte van 1999/2000. Afgewacht moet worden of deze aantallen achteraf als uitbijters moeten worden beschouwd.

Bij de gegevens betreffende bestemming en herkomst van uitgaande en inkomende studenten is voor een indeling naar geïndustrialiseerde landen en ontwikkelingslanden gekozen. Sommige landen bevinden zich op het grensvlak van deze twee categorieën en dit kan in verschillende faculteiten tot een andere toedeling hebben geleid. Ook de gehanteerde typen onderwijs (klinisch en regulier (keuze-)onderwijs en onderzoek) zijn niet altijd scherp te scheiden en er kunnen problemen ontstaan bij de toedeling van een individueel buitenlands studieverblijf aan een van de onderscheiden typen, als dat studieprogramma bij de registratie onvoldoende duidelijk is omschreven. Bovendien is het denkbaar dat sommige programma's in twee categorieën kunnen worden ondergebracht.

Met inachtneming van deze kanttekeningen zijn de volgende conclusies te trekken. Aan iedere faculteit zijn er zowel studenten die onderwijs volgen in geïndustrialiseerde landen als in ontwikkelingslan- den. In geïndustrialiseerde landen wordt maar weinig deelgenomen aan regulier onderwijs. Klinisch onderwijs en met name onderzoek zijn hier het meest in trek. Faciliteiten voor onderzoek en bekendheid van onderzoeksgroepen in bijvoorbeeld Europa of de Verenigde Staten verklaren waarschijnlijk de voorkeur voor onderzoek tijdens stages in geïndustrialiseerde landen. In ontwikkelingslanden nemen studenten vooral deel aan klinisch onderwijs, hetgeen mogelijk enerzijds te verklaren is uit de behoefte in veel ontwikkelingslanden aan medisch geschoold personeel en anderzijds waarschijnlijk uit de interesse van Nederlandse medische studenten om al tijdens de studie in klinische zorg te participeren. Vrijwel alle overige studenten die een ontwikkelingsland bezoeken, volgen daar een wetenschapsstage.

Met betrekking tot de herkomst van inkomende studenten uit geïndustrialiseerde landen en ontwikkelingslanden wordt per faculteit een evenwicht het dichtst benaderd door de UMCSR (58\% en $42 \%$ ), terwijl het grootste verschil zich voordoet aan het AMC-A (95\% en 5\%). Het is overigens aan de afzonderlijke faculteiten om te bepalen of zij een dergelijk evenwicht willen nastreven of niet. Van de inkomende studenten uit zowel geïndustrialiseerde landen als ontwikkelingslanden neemt tweederde deel aan klinisch of regulier (keuze-)onderwijs. Het is onwaarschijnlijk dat veel van deze studenten het Nederlands beheersen. Kennelijk worden deze programma's door de faculteiten in het Engels aangeboden. Dat is bijvoorbeeld de verklaring voor de relatief grote deelname van inkomende studenten aan het reguliere onderwijs van de UM. Deze faculteit biedt een drietal reguliere onderwijsblokken in het vierde jaar in de Engelse taal aan. Dat aan het LUMC niet hetzelfde effect optreedt, hoewel daar het 
eerste semester van het tweede jaar in de Engelse taal wordt aangeboden, is te verklaren uit het feit dat er aan het LUMC in dat semester onvoldoende capaciteit is om grotere aantallen buitenlandse studenten te ontvangen.

Alle deelnemende faculteiten hebben maatregelen genomen om de kwaliteit van onderwijs in het buitenland te bewaken. De kwaliteitszorg verschilt per faculteit. Het zou wellicht aanbeveling verdienen om in bepaalde opzichten tot een gemeenschappelijke strategie te komen. Zo zouden er tussen de faculteiten afspraken kunnen worden gemaakt op welke wijze beoordelingen van prestaties van uitgaande studenten door docenten in het buitenland gecombineerd kunnen worden met beoordelingen door docenten aan de thuisfaculteit.

Met betrekking tot internationalisering van het curriculum is het beeld zeer divers. In alle zeven faculteiten wordt wel aandacht besteed aan enkele van de aspecten van internationalisering. Daarbij moet worden aangetekend dat het onderwijs in die onderwerpen vaak facultatief (extracurriculair of als keuzeonderwijs) wordt aangeboden. Met betrekking tot de studenten van de faculteiten in de grote steden is gesteld dat zij tijdens hun co-assistentschappen vanzelfsprekend leren omgaan met allochtone patiënten. Het verwerven van die vaardigheid vereist waarschijnlijk toch ook expliciete aandacht in het curriculum. Uit de ons beschikbare gegevens valt evenwel niet op te maken of die expliciete aandacht ook gegeven wordt. Het ontbreken van aandacht voor dat aspect in de reguliere curricula van de andere faculteiten moet als een lacune worden beschouwd, omdat afgestudeerden in hun vervolgopleiding of professioneel functioneren in veel gevallen alsnog met allochtone patiënten kunnen worden geconfronteerd. Om recht te doen aan alle aspecten van internationalisering verdient het aanbeveling dat de faculteiten aspecten van internationalisering die nu nog als facultatief onderwijs worden aangeboden, opnemen in het reguliere curriculum.

Uit de antwoorden op de vraag naar de stimuleringsmaatregelen die het meest van invloed zijn geweest op internationalisering komen over het algemeen maatregelen op universitair en facultair niveau als belangrijkste naar voren. Deze uitkomst dient met enige voorzichtigheid te worden geïnterpreteerd. Het lijdt weinig twijfel dat in de laatste twee decennia van de vorige eeuw het Erasmus-programma van de EC ook in de medische faculteiten van grote invloed is geweest op het aanzwengelen van internationalisering. De daardoor teweeggebrachte veranderde attitude ten opzichte van internationalisering werkt waarschijnlijk nog door bij universitaire en facultaire bestuurders. Hun stimuleringsmaatregelen worden door de coördinatoren internationalisering nu vaak als het belangrijkst voor de internationalisering van het medisch onderwijs gepercipieerd, maar als dezelfde vraag tien jaar geleden was voorgelegd, dan hadden hun antwoorden waarschijnlijk meer recht gedaan aan de invloed van het Erasmus-programma.

\section{Literatuur}

1. Majoor GD, Willemstein SC. Internationalisering van het medisch onderwijs. Ned Tijdschr Geneeskd 1996;140:100-2.

2. Metz JCM, Verbeek-Weel AAM, Huisjes HJ. Raamplan 2001 artsopleiding. Nijmegen: Mediagroep Nijmegen; 2001.

3. Raad voor de Volksgezondheid \& Zorg (RVZ) Interculturalisatie van de gezondheidszorg. Zoetermeer; 2000.

4. Wieringen JCM van, Kijlstra MA, Schulpen TWJ. Interculturalisatie van het medisch onderwijs in Nederland - een inventarisatie bij de faculteiten geneeskunde. Utrecht: Centre for Migration and Child Health; 2001. 
5. Teichler U, Maiworm F. The Erasmus experience: major findings of the Erasmus evaluation research project. Universität Gesamthochschule Kassel, Wissenschaftliches Zentrum für Berufsund Hochschulforschung; 1996.

6. Bourgeois M. Erasmus and mobility in medical studies. Brussels: Commission of the European Communities. Task force human resources, training and youth; 1992.

7. VSNU. Onderwijsvisitatie Geneeskunde en Gezondheidswetenschappen. Utrecht: Vereniging van Samenwerkende Nederlandse Universiteiten; 1992.

8. Majoor GD. Internationalisering voor studenten geneeskunde: anders dan andere? In: Metz JCM, Scherpbier AJJA, Houtkoop E, redactie. Gezond onderwijs - 2. Nijmegen: Universitair Publikatiebureau UMCSR; 1992. p. 240-4.

9. Majoor GD. Internationalisering van curricula voor het gezondheidsonderwijs. In: Houtkoop E, Pols J, Pollemans MC, Scherpbier AJJA, Verwijnen GM, redactie. Gezond onderwijs - 3. Alphen aan den Rijn: Haasbeek; 1993. p. 273-5.

10. VSNU. Onderwijsvisitatie Geneeskunde en Gezondheidswetenschappen. Utrecht: Vereniging van Samenwerkende Nederlandse Universiteiten; 1997.

De auteurs:

Dr. Gerard Majoor is als coördinator internationalisering verbonden aan het Onderwijsinstituut Geneeskunde,Universiteit Maastricht, g.majoor@oifdg.unimaas.nl.

Drs. Susan Niemantsverdriet is als AIO werkzaam in het thema Onderzoek van Onderwijs van de Universiteit Maastricht,s.niemantsverdriet@oifdg.unimaas.nl.
Sonja Groen is als coördinator internationalisering verbonden aan de Afdeling Onderwijs en Studentzaken van het Leids Universitair Medisch Centrum,m.m.groen@ lumc.nl.

Ina ten Have is hoofd van het Bureau Internationale Betrekkingen van het Academisch Medisch Centrum van de Universiteit van Amsterdam, g.e.tenhave@amc.uva.nl.

Dr. Caesar Hulstaert is als coördinator internationalisering verbonden aan het Faculteitsbureau Medische Wetenschappen van de Rijksuniversiteit Groningen, c.e.hulstaert@med.rug.nl.

Maria Nijenhuis is als coördinator internationale zaken verbonden aan het Onderwijsinstituut van het Universitair Medisch Centrum Utrecht, foreign.exchange@ med.uu.nl.

Drs. Marc Vorstenbosch is coördinator internationalisering verbonden aan de Dienst Onderwijs- en Studentzaken van het Universitair Medisch Centrum St. Radboud in Nijmegen,m.vorstenbosch@osz.kun.nl.

Dr. Sjoert Willemstein is manager internationale betrekkingen van het Erasmus Medisch Centrum in Rotterdam,willemstein@facb.fgg.eur.nl.

Met uitzondering van mw. Niemantsverdriet zijn allen lid van de Werkgroep Internationalisering van het Disciplineoverlegorgaan Medische Wetenschappen van de Vereniging van Samenwerkende Nederlandse Universiteiten.

Correspondentieadres:

Dr. G.D. Majoor, Bureau Internationale Betrekkingen, Onderwijsinstituut Geneeskunde, Universiteit Maastricht, Postbus 616, 6200 MD Maastricht, tel: 0433881816,fax 043-3884142, g.majoor@oifdg.unimaas.nl.

\section{Summary}

Introduction: Over the past 15 years internationalisation of medical education has attracted broad attention. This paper reports on the state of the art with respect to internationalisation in seven Dutch Faculties of Medicine for the academic year 2000/2001. The study examined the numbers of outgoing and incoming students, quality assurance, aspects of internationalisation in the regular curriculum and the impact of incentive policies on internationalisation. Method: Internationalisation co-ordinators of the eight Dutch medical faculties were electronically surveyed about internationalisation.

Results: Seven co-ordinators completed the questionnaire. All faculties send students abroad (mean: 107; range: 53-243) and receive foreign students (mean: 38; range: 12-77). Between 1998 and 2001 the average annual number of incoming students showed a gradual increase from 27 to 38. In industrialised countries students predominantly participate in research; in developing countries clinical training is most popular. On average incoming students participate to the same extent in the regular curriculum, clinical training and research. In all faculties procedures are in place to assure the quality of programmes abroad. Internationalisation is included in the undergraduate curricula, but often only as electives. Incentive policies implemented by their own university or medical faculty are perceived as most effective by the co-ordinators. Conclusions: Student mobility differed significantly between faculties. It is recommended that the faculties should mutually adjust their quality assurance programmes. Internationalisation would benefit from integration of internationalisation in the regular curricula. The respondents indicated that local incentive policies at faculty or university level are most effective in promoting internationalisation. (Majoor GD, Niemantsverdriet S, Groen MM, Have GEA ten, Hulstaert CE, Nijenhuis MAJ, Vorstenbosch MATM, Willemstein SC. Internationalisation of medical education in the Dutch faculties of medicine: the state of the art. Dutch Journal of Medical Education 2003;22(1):18-27.) 